\title{
Effect of Fertilization Modules on the Growth and Yield of Rice (Oryza sativa L.) in Tarai Region of Uttarakhand, India
}

\author{
E. K. Arun $^{1 *}$ and Brajkishor Prajapati ${ }^{2}$ \\ ${ }^{1}$ Soil Conservation Officer, Department of Soil Survey and Soil Conservation, \\ Govt. of Kerala, India \\ ${ }^{2}$ Division of Agronomy, RHSKVK, Balaghat (M.P.), India \\ *Corresponding author
}

\section{A B S T R A C T}

\section{Keywords}

Tarai region,

Fertilization,

Growth and yield,

Rice

Article Info

Accepted:

26 April 2020

Available Online:

10 May 2020
Field experiment was conducted to evaluate effect of planting methods and fertilization modules on the growth and yield of rice (Oryza sativa L.) in tarai region of Uttarakhand at the Norman E. Borlaug Crop Research Centre, Govind Ballabh Pant University of Agriculture and Technology, Pantnagar, during the Kharif season of 2010-11. The experiment was laid out in randomized block design with four replications and comprising five treatments i.e. $\mathrm{T}_{1}$ - conventional method of transplanting with RDF (150:60:40 kg/ha $\left.\mathrm{N}: \mathrm{P}_{2} \mathrm{O}_{5}: \mathrm{K}_{2} \mathrm{O}+0.5 \% \quad \mathrm{ZnSO}_{4}\right), \quad \mathrm{T}_{2}$-conventional method of transplanting with $180 \mathrm{~kg}$ $\mathrm{N}+$ Sesbania green manuring and recommended phosphorus, potassium and $0.5 \% \mathrm{ZnSO}_{4}$, $\mathrm{T}_{3}$-conventional method of transplanting with $10 \%$ extra RDF (165:66:44 $\mathrm{kg} / \mathrm{ha}$ $\left.\mathrm{N}: \mathrm{P}_{2} \mathrm{O}_{5}: \mathrm{K}_{2} \mathrm{O}+0.5 \% \mathrm{ZnSO}_{4}\right), \mathrm{T}_{4}$-direct rice seeding with recommended dose of NPK and $0.5 \% \mathrm{ZnSO}_{4}$ and $\mathrm{T}_{5}$-direct rice seeding with $10 \%$ extra recommended dose of NPK and $0.5 \% \mathrm{ZnSO}_{4}$. The analysis of data indicated that values of growth attributes like plant height, number of shoots $/ \mathrm{m}^{2}$ and dry matter accumulation $\left(\mathrm{g} / \mathrm{m}^{2}\right)$ was maximum due to $\mathrm{T}_{2^{-}}$ conventional method of transplanting with 180:60:40 kg/ha N: $\mathrm{P}_{2} \mathrm{O}_{5}: \mathrm{K}_{2} \mathrm{O}+0.5 \%$ $\mathrm{ZnSO}_{4}+$ Sesbania green manuring followed by $\mathrm{T}_{3}$-Conventional method of transplanting with $10 \%$ extra RDF (165:66:44 kg/ha $\mathrm{N}: \mathrm{P}_{2} \mathrm{O}_{5}: \mathrm{K}_{2} \mathrm{O}+0.5 \% \mathrm{ZnSO}_{4}$. Whereas, the highest straw yield (67.25 q/ha), biological yield (129.54 q/ha) and grain yield (62.39 q/ha) was due to $\mathrm{T}_{2}$-conventional method of transplanting with 180:60:40 kg/ha N: $\mathrm{P}_{2} \mathrm{O}_{5}: \mathrm{K}_{2} \mathrm{O}+0.5 \%$ $\mathrm{ZnSO}_{4}+$ Sesbania green manuring followed by $\mathrm{T}_{3}$-Conventional method of transplanting with $10 \%$ extra RDF (165:66:44 kg/ha $\mathrm{N}: \mathrm{P}_{2} \mathrm{O}_{5}: \mathrm{K}_{2} \mathrm{O}+0.5 \% \mathrm{ZnSO}_{4}$ compared with other treatments. The results showed that green manuring with $\mathrm{NPK}+\mathrm{Zn}$ had direct beneficial effect of growth and yield of rice.

\section{Introduction}

Indian agriculture is now facing many problems like raising or lowering of water table, nutrient imbalance, soil degradation, salinity, resurgence of pests and diseases, environmental pollution and decline in farm profit (Pacharne, 2017). Rice is dietary and protein currency of Indian population and supplies $31 \%$ of total calories required. Rice is cultivated world-wide over an area of about 160.68 million ha with an annual production 
of about 650.19 million tonnes (Tomar, 2018). In India, rice occupies an area of 43.79 million ha with a production of 112.91 million tonnes with average productivity of $2578 \mathrm{~kg} / \mathrm{ha} \quad$ (Agricultural Statistics, 2018).Demand for rice growing is increasing every year and it is estimated that requirement would be 140 million tonnes by 2025 (Kumar, 2017).India has the largest area among rice growing countries and it stands second in production next to China. Rice is grown under 4 major ecosystems: irrigated, rainfed lowland, rainfed upland and flood prone. More than half of rice area $(55 \%)$ is rainfed and distribution wise $80 \%$ of rainfed rice area is in eastern India, making its cultivation vulnerable to vagaries of monsoon. Continuous puddling for rice cultivation over decades has led to deterioration of soil physical properties through structural breakdown of soil aggregates and capillary pores and clay dispersion, thereby restricting germination and rooting of succeeding crops. Added to this, limited or no use of organic manures/crop residue (Ghosh et al., 2016) and imbalanced use of mineral fertilizers (Brar et al., 2013) have further soil quality deterioration. Transplanting of rice seedling being a labour-intensive and expensive operation, it need to be substituted by direct seeding which could reduce labour need by more than $20 \%$ in terms of working hour. Many Asian countries are now increasingly shifting to direct wet-seeded method of growing rice. However, the practice of direct wet seeding rice is very negligible in India. In India direct seeded rice production has been achieved about 2-12\% higher grain yield than transplanting (Husain et al., 2003).

\section{Materials and Methods}

The experiment was conducted during Kharif season of 2010-11 at N. E. Borlaug Crop Research Centre of the Govind Ballabh Pant University of Agriculture and Technology,
Pantnagar, Udham Singh Nagar, Uttarakhand, India. The N. E. Borlaug Crop Research Centre is situated in the Tarai belt of Shivalik range of Himalayas with humid sub-tropical type of climate at latitude of $29^{\circ} \mathrm{N}$ and longitude of $79.3^{\circ} \mathrm{E}$ and situated at an altitude of $243.84 \mathrm{~m}$ above the mean sea level. The soil of experimental site was silty clay loam with neutral reaction $(7.60 \mathrm{pH})$. The nutritional status of soil was rich in organic carbon (1.23\%), available nitrogen (246.00 $\mathrm{kg} / \mathrm{ha}$ ), available phosphorus (32 kg/ha) and available potassium (143 kg/ha) obtained by following Walkley and Black (1934), Subbiah and Asija (1956), Olsen et al., (1954) and Hanway and Heidel (1952). The experiment was laid out in randomized block design with four replications and comprising five treatments i.e. $\mathrm{T}_{1^{-}}$Conventional method of transplanting with RDF (150:60:40 kg/ha $\left.\mathrm{N}: \mathrm{P}_{2} \mathrm{O}_{5}: \mathrm{K}_{2} \mathrm{O}+0.5 \% \quad \mathrm{ZnSO}_{4}\right), \mathrm{T}_{2}$-Conventional method of transplanting with $180 \mathrm{~kg}$ $\mathrm{N}+$ Sesbania green manuring and recommended phosphorus, potassium and $0.5 \% \mathrm{ZnSO}_{4}, \mathrm{~T}_{3}$-Conventional method of transplanting with $10 \%$ extra RDF (165:66:44 $\left.\mathrm{kg} / \mathrm{ha} \mathrm{N}: \mathrm{P}_{2} \mathrm{O}_{5}: \mathrm{K}_{2} \mathrm{O}+0.5 \% \quad \mathrm{ZnSO}_{4}\right), \mathrm{T}_{4}$-Direct rice seeding with recommended dose of NPK and $0.5 \% \quad \mathrm{ZnSO}_{4}$ and $\mathrm{T}_{5}$-Direct rice seeding with $10 \%$ extra recommended dose of NPK and $\quad 0.5 \% \quad \mathrm{ZnSO}_{4}$. For conventional transplanting treatments, nitrogen $(150,165$ and $180 \mathrm{~kg} \mathrm{~N} / \mathrm{ha}$ ), phosphorus (60 kg $\mathrm{P}_{2} \mathrm{O}_{5} / \mathrm{ha}$ ) and potassium (40 $\mathrm{kg} \mathrm{K} 2 \mathrm{O} / \mathrm{ha}$ ) were supplied through urea, single superphosphate, and muriate of potash, respectively. Half of the nitrogen and total quantities of phosphorus and potash were applied prior to transplanting on drained puddled surface. The remained quantity of half nitrogen was top dressed in two equal splits one at active tillering followed by 5-7 days before panicle initiation stage. For direct rice seeding, mixed fertilizer NPK (12:32:16) was used @ 200 $\mathrm{kg} / \mathrm{ha}$ with seed drill as basal. In addition, remaining potash was used through MOP as 
basal broadcast and remaining $\mathrm{N}$ was top dressed in two equal amounts through urea. The foliar $0.5 \% \mathrm{ZnSO}_{4}$ was sprayed 10 and 20 days after transplanting/seeding of rice. The certified seed of rice cultivar "PR 114" were treated with bavistin fungicide at 2.0 $\mathrm{g} / \mathrm{kg}$ seed before sowing in the nursery. Seeds were soaked for $24 \mathrm{hrs}$ and incubated in moist gunny bags for 2 days. Pre-germinated seeds were broadcast uniformly on nursery beds of $1 \mathrm{~m}$ width separated by channels of $30 \mathrm{~cm}$ width and $15 \mathrm{~cm}$ depth. Soil: farmyard manure mixture (1:1) was spread in a thin layer for covering the seeds. The beds were irrigated daily and thoroughly before lifting the seedlings. The nursery beds were irrigated a day before uprooting of seedlings so as to make the soil soft. Seedlings were uprooted one by one and the roots were washed to remove the mud. Seedlings were than transplanted in rows with the help of nylon rope at $20 \mathrm{~cm} \times 10 \mathrm{~cm}$. Two seedlings were transplanted per hill. The size of each net plot was $15 \mathrm{~m}^{2}(5 \mathrm{~m} \times 3 \mathrm{~m})$. In direct seeded rice treatment at proper tilth, one ploughing followed by two cross-harrowing and levelling was done to ensure proper germination. Harvesting of rice crop was undertaken for harvest at maturity stage with the help of sickle. Grain yield thus obtained from each net plot were converted to $\mathrm{kg} / \mathrm{ha}$. Biological yield was obtained by addition of grain and straw yields and was expressed in $\mathrm{kg} / \mathrm{ha}$. The harvest index (HI) was calculated by dividing economical yield (grain yield) by the biological yield (grain and straw) and represented in percentage (Donald and Hamblin, 1976). The experimental data were analyzed using analysis of variance technique appropriate to randomized block design with the help of computer software STPR 3 developed by the Department of Mathematics and Statistics, College of Basic Science and Humanities. The critical differences at 5\% level of probability were calculated for testing the significance of difference between any two means wherever ' $F$ ' test was significant (Snedecor and Cochran, 1967).

\section{Results and Discussion}

\section{Crop growth parameters}

\section{Plant height (cm)}

The plants height of rice crop was significantly higher due to $\mathrm{T}_{2^{-}}$conventional method of transplanting with 180:60:40 kg/ha $\mathrm{N}: \mathrm{P}_{2} \mathrm{O}_{5}: \mathrm{K}_{2} \mathrm{O}+0.5 \% \quad \mathrm{ZnSO}_{4}+$ Sesbania green manuring than remaining treatments at 30 DAS. At 60 DAS, plant height was unaffected due to different treatments but tallest plant height was caused by $\mathrm{T}_{2}$-conventional method of transplanting with $180 \mathrm{~kg} \mathrm{~N}+$ sesbania green manuring and recommended phosphorus, potassium and $0.5 \% \quad \mathrm{ZnSO}_{4}$. Plant height was increased 5.83, 16.49, 19.51 and 5.14 by conventional method of transplanting with 180:60:40 $\mathrm{kg} / \mathrm{ha}$ $\mathrm{N}: \mathrm{P}_{2} \mathrm{O}_{5}: \mathrm{K}_{2} \mathrm{O}+0.5 \% \quad \mathrm{ZnSO}_{4}+$ Sesbania green manuring over $\mathrm{T}_{1}$-conventional transplanting with RDF (150:60:40 $\mathrm{kg} / \mathrm{ha}$ $\left.\mathrm{N}: \mathrm{P}_{2} \mathrm{O}_{5}: \mathrm{K}_{2} \mathrm{O}+0.5 \% \quad \mathrm{ZnSO}_{4}\right), \mathrm{T}_{3}$-conventional method of transplanting with $10 \%$ extra RDF (165:66:44 kg/ha N: $\mathrm{P}_{2} \mathrm{O}_{5}: \mathrm{K}_{2} \mathrm{O}+0.5 \% \mathrm{ZnSO}_{4}$ ), $\mathrm{T}_{4}$-direct seeded rice with recommended dose of NPK and $0.5 \% \mathrm{ZnSO}_{4}$ and $\mathrm{T}_{5}$-direct seeded rice with $10 \%$ extra recommended dose of NPK and $0.5 \% \quad \mathrm{ZnSO}_{4}$, respectively. At 90 DAS and maturity stage, plants height of rice crop was significantly higher due to $T_{2^{-}}$ conventional method of transplanting with 180:60:40 kg/ha $\quad \mathrm{N}: \mathrm{P}_{2} \mathrm{O}_{5}: \mathrm{K}_{2} \mathrm{O}+0.5 \%$ $\mathrm{ZnSO}_{4}+$ Sesbania green manuring compared with $\mathrm{T}_{4}$-direct seeded rice with recommended dose of NPK and $0.5 \% \mathrm{ZnSO}_{4}$ and at par with remaining treatments. The higher plant height in conventionally puddled and transplanted crop with $180 \mathrm{~kg} \mathrm{~N}$, recommended $\mathrm{P}, \mathrm{K}$ and $\mathrm{Zn}$ and sesbania green manuring might be due to higher rate of $\mathrm{N}$ application which supported plant growth in terms of shoot 
height and decomposition of sesbania green manure made available regular available $\mathrm{N}$ due to mineralization to crop. In situ, sesbania green manuring on decomposition and subsequent mineralization provides $30-50 \mathrm{Kg}$ $\mathrm{N} /$ ha (Table 1).

\section{Number of shoots $/ \mathrm{m}^{2}$}

Significantly higher number of shoots $/ \mathrm{m}^{2}$ was recorded due to $\mathrm{T}_{5}$-direct seeded rice with $10 \%$ extra recommended dose of NPK and $0.5 \% \quad \mathrm{ZnSO}_{4}$ over remaining treatments except $\mathrm{T}_{2}$-conventional method of transplanting with 180:60:40 $\mathrm{kg} / \mathrm{ha}$ $\mathrm{N}: \mathrm{P}_{2} \mathrm{O}_{5}: \mathrm{K}_{2} \mathrm{O}+0.5 \% \quad \mathrm{ZnSO}_{4}+$ Sesbania green manuring and $\mathrm{T}_{4}$-direct seeded rice with recommended dose of NPK and $0.5 \% \mathrm{ZnSO}_{4}$ at $30 \mathrm{DAS}$. At $60 \mathrm{DAS}$, number of shoots $/ \mathrm{m}^{2}$ was significantly more due to $\mathrm{T}_{3}$-conventional transplanting with $10 \%$ extra RDF (165:66:44 $\left.\mathrm{kg} / \mathrm{ha} \quad \mathrm{N}: \mathrm{P}_{2} \mathrm{O}_{5}: \mathrm{K}_{2} \mathrm{O}+0.5 \% \quad \mathrm{ZnSO}_{4}\right)$ over $\mathrm{T}_{1^{-}}$ conventional transplanting with $\mathrm{RDF}$ (150:60:40 kg/ha $\mathrm{N}: \mathrm{P}_{2} \mathrm{O}_{5}: \mathrm{K}_{2} \mathrm{O}+0.5 \% \quad \mathrm{ZnSO}_{4}$ ) and $\mathrm{T}_{4}$-direct seeded rice with recommended dose of NPK and $0.5 \% \mathrm{ZnSO}_{4}$ but at par with remaining treatments. At 90 DAS and maturity stage, significantly higher number of shoots $/ \mathrm{m}^{2}$ was caused by $\mathrm{T}_{2^{-}}$conventional method of transplanting with 180:60:40 kg/ha $\mathrm{N}: \mathrm{P}_{2} \mathrm{O}_{5}: \mathrm{K}_{2} \mathrm{O}+0.5 \% \quad \mathrm{ZnSO}_{4}+$ Sesbania green manuring compared with $\mathrm{T}_{1}$-conventional transplanting with RDF (150:60:40 kg/ha $\left.\mathrm{N}: \mathrm{P}_{2} \mathrm{O}_{5}: \mathrm{K}_{2} \mathrm{O}+0.5 \% \mathrm{ZnSO}_{4}\right)$ and statistically at par with remaining treatments.

Data revealed that combined application of Zn with NPK+green manuring crop increased the number of shoots $/ \mathrm{m}^{2}$. It might be owing to adequate and balance application of nutrients increases the availability and uptake of other essential nutrients resulted in increased metabolic activities. Similar trend was found in the findings of Umar et al., (2004).

\section{Dry matter accumulation $\left(\mathrm{g} / \mathrm{m}^{2}\right)$}

Dry matter accumulation of plants were significantly higher due to $\mathrm{T}_{5}$-direct seeded rice with $10 \%$ extra recommended dose of NPK and $0.5 \% \quad \mathrm{ZnSO}_{4}$ over remaining treatments, which was at par with $\mathrm{T}_{4}$-direct seeded rice with recommended dose of NPK and $0.5 \% \mathrm{ZnSO}_{4}$ at $30 \mathrm{DAS}$. At $60 \mathrm{DAS}$ and maturity stage, the significantly maximum dry matter accumulation of plants was caused by $\mathrm{T}_{2}$ - conventional method of transplanting with 180:60:40 $\mathrm{kg} / \mathrm{ha} \quad \mathrm{N}: \mathrm{P}_{2} \mathrm{O}_{5}: \mathrm{K}_{2} \mathrm{O}+0.5 \%$ $\mathrm{ZnSO}_{4}+$ Sesbania green manuring over $\mathrm{T}_{1^{-}}$ conventional transplanting with $\mathrm{RDF}$ (150:60:40 kg/ha $\left.\mathrm{N}: \mathrm{P}_{2} \mathrm{O}_{5}: \mathrm{K}_{2} \mathrm{O}+0.5 \% \quad \mathrm{ZnSO}_{4}\right)$ and $\mathrm{T}_{4}$-direct seeded rice with recommended dose of NPK and $0.5 \% \mathrm{ZnSO}_{4}$ but at par with remaining treatments. At 90 DAS, dry matter accumulation of plants were significantly higher due to $\mathrm{T}_{3}$-conventional transplanting with $10 \%$ extra RDF (165:66:44 kg/ha $\left.\mathrm{N}: \mathrm{P}_{2} \mathrm{O}_{5}: \mathrm{K}_{2} \mathrm{O}+0.5 \% \mathrm{ZnSO}_{4}\right)$ as compared with $\mathrm{T}_{1}$-conventional transplanting with $\mathrm{RDF}$ (150:60:40 kg/ha $\mathrm{N}: \mathrm{P}_{2} \mathrm{O}_{5}: \mathrm{K}_{2} \mathrm{O}+0.5 \% \quad \mathrm{ZnSO}_{4}$ ) and $\mathrm{T}_{4}$-direct seeded rice with recommended dose of NPK and $0.5 \% \mathrm{ZnSO}_{4}$. It might be due to integrated nutrient management provided the balance and sufficient nutrition to crop for growth and development, which caused in higher dry matter accumulation. Similar results were obtained by Singh and Khan (2000).

\section{Yield attributes of rice}

\section{Number of panicles $/ \mathrm{m}^{2}$}

Significantly maximum number of panicles $/ \mathrm{m}^{2}$ was recorded with $\mathrm{T}_{2^{-}}$ conventional method of transplanting with 180:60:40 $\mathrm{kg} / \mathrm{ha} \quad \mathrm{N}: \mathrm{P}_{2} \mathrm{O}_{5}: \mathrm{K}_{2} \mathrm{O}+0.5 \%$ $\mathrm{ZnSO}_{4}+$ Sesbania green manuring over $\mathrm{T}_{1^{-}}$ conventional transplanting with $\mathrm{RDF}$ (150:60:40 kg/ha $\mathrm{N}: \mathrm{P}_{2} \mathrm{O}_{5}: \mathrm{K}_{2} \mathrm{O}+0.5 \% \mathrm{ZnSO}_{4}$ ), which is statistically at par with $\mathrm{T}_{3^{-}}$ 
conventional transplanting with $10 \%$ extra RDF (165:66:44 kg/ha $\mathrm{N}: \mathrm{P}_{2} \mathrm{O}_{5}: \mathrm{K}_{2} \mathrm{O}+0.5 \%$ $\left.\mathrm{ZnSO}_{4}\right), \quad \mathrm{T}_{4}$-direct seeded rice with recommended dose of $\mathrm{NPK}+0.5 \% \mathrm{ZnSO}_{4}$ and $\mathrm{T}_{5}$-direct seeded rice with $10 \%$ extra recommended dose of NPK $0.5 \% \quad \mathrm{ZnSO}_{4}$, respectively. The possible reason for higher number of panicles $/ \mathrm{m}^{2}$ in conventional method of transplanting with 180:60:40 kg/ha $\mathrm{N}: \mathrm{P}_{2} \mathrm{O}_{5}: \mathrm{K}_{2} \mathrm{O}+0.5 \% \quad \mathrm{ZnSO}_{4}+$ Sesbania green manuring could be the organic manure, which help to increase the soil fertility through improvement in soil physical, chemical and biological characteristics and higher $\mathrm{N}$ availability which is essential for crop growth and development. These results corroborate with the finding of Singh and Brar (1994).

\section{Panicle length $(\mathrm{cm})$}

Panicle length was significantly higher with $\mathrm{T}_{2}$ - conventional method of transplanting with 180:60:40 $\mathrm{kg} / \mathrm{ha} \quad \mathrm{N}: \mathrm{P}_{2} \mathrm{O}_{5}: \mathrm{K}_{2} \mathrm{O}+0.5 \%$ $\mathrm{ZnSO}_{4}+$ Sesbania green manuring over $\mathrm{T}_{5^{-}}$ direct seeded rice with $10 \%$ extra recommended dose of NPK $0.5 \% \quad \mathrm{ZnSO}_{4}$, which is statistically at par with $\mathrm{T}_{1^{-}}$ conventional transplanting with $\mathrm{RDF}$ (150:60:40 kg/ha $\mathrm{N}: \mathrm{P}_{2} \mathrm{O}_{5}: \mathrm{K}_{2} \mathrm{O}+0.5 \% \mathrm{ZnSO}_{4}$ ), $\mathrm{T}_{3}$-conventional transplanting with $10 \%$ extra RDF (165:66:44 kg/ha $\mathrm{N}: \mathrm{P}_{2} \mathrm{O}_{5}: \mathrm{K}_{2} \mathrm{O}+0.5 \%$ $\left.\mathrm{ZnSO}_{4}\right)$ and $\mathrm{T}_{4}$-direct seeded rice with recommended dose of NPK+ $0.5 \%$ $\mathrm{ZnSO}_{4}$,respectively. The increased in panicle length was 4.59 and 8.26 per cent, respectively by $\mathrm{T}_{2}$-conventional method of transplanting with 180:60:40 $\mathrm{kg} / \mathrm{ha}$ $\mathrm{N}: \mathrm{P}_{2} \mathrm{O}_{5}: \mathrm{K}_{2} \mathrm{O}+0.5 \% \quad \mathrm{ZnSO}_{4}+$ Sesbania green manuring over $\mathrm{T}_{4}$-direct seeded rice with recommended dose of $\mathrm{NPK}+0.5 \% \mathrm{ZnSO}_{4}$ and $\mathrm{T}_{5}$-direct seeded rice with $10 \%$ extra recommended dose of NPK $0.5 \% \mathrm{ZnSO}_{4}$.

\section{Number of grains / panicle}

Number of grains/panicle was significantly more due to $\mathrm{T}_{3}$-conventional transplanting with $10 \%$ extra RDF (165:66:44 kg/ha $\left.\mathrm{N}: \mathrm{P}_{2} \mathrm{O}_{5}: \mathrm{K}_{2} \mathrm{O}+0.5 \% \quad \mathrm{ZnSO}_{4}\right)$ as compared to $\mathrm{T}_{4}$-direct seeded rice with recommended dose of $\mathrm{NPK}+0.5 \% \mathrm{ZnSO}_{4}$, which was at par with remaining treatments. Number of grains/panicle was increased 12.23, 15.83 and 9.46 per cent by $\mathrm{T}_{3}$-conventional transplanting with $10 \%$ extra RDF (165:66:44 kg/ha $\left.\mathrm{N}: \mathrm{P}_{2} \mathrm{O}_{5}: \mathrm{K}_{2} \mathrm{O}+0.5 \% \quad \mathrm{ZnSO}_{4}\right)$ over $\mathrm{T}_{1^{-}}$ conventional transplanting with $\mathrm{RDF}$ (150:60:40 kg/ha $\mathrm{N}: \mathrm{P}_{2} \mathrm{O}_{5}: \mathrm{K}_{2} \mathrm{O}+0.5 \% \mathrm{ZnSO}_{4}$ ), $\mathrm{T}_{4}$-direct seeded rice with recommended dose of NPK+ $0.5 \% \mathrm{ZnSO}_{4}$ and $\mathrm{T}_{5}$-direct seeded rice with $10 \%$ extra recommended dose of NPK $0.5 \% \quad \mathrm{ZnSO}_{4}$, respectively. It might be owing to application of organic manures plus fertilizers increased yields parameters of rice crop (Ahmad et al., 1998).

\section{Grain weight / panicle (g)}

Significantly maximum grain weight/panicle was recorded with $\mathrm{T}_{2^{-}}$conventional method of transplanting with 180:60:40 $\mathrm{kg} / \mathrm{ha}$ $\mathrm{N}: \mathrm{P}_{2} \mathrm{O}_{5}: \mathrm{K}_{2} \mathrm{O}+0.5 \% \quad \mathrm{ZnSO}_{4}+$ Sesbania green manuring over $\mathrm{T}_{1}$-conventional transplanting with RDF (150:60:40 $\mathrm{kg} / \mathrm{ha}$ $\left.\mathrm{N}: \mathrm{P}_{2} \mathrm{O}_{5}: \mathrm{K}_{2} \mathrm{O}+0.5 \% \quad \mathrm{ZnSO}_{4}\right), \mathrm{T}_{4}$-direct seeded rice with recommended dose of $\mathrm{NPK}+0.5 \%$ $\mathrm{ZnSO}_{4}$ and $\mathrm{T}_{5}$-direct seeded rice with $10 \%$ extra recommended dose of NPK $0.5 \%$ $\mathrm{ZnSO}_{4}$, respectively and statistically at par with $\mathrm{T}_{3}$-conventional transplanting with $10 \%$ extra RDF (165:66:44 $\mathrm{kg} / \mathrm{ha}$ $\left.\mathrm{N}: \mathrm{P}_{2} \mathrm{O}_{5}: \mathrm{K}_{2} \mathrm{O}+0.5 \% \mathrm{ZnSO}_{4}\right)$.

Grain weight/panicle was increased 19.36 and 15.60 per cent by $\mathrm{T}_{2^{-}}$conventional method of transplanting with 180:60:40 $\mathrm{kg} / \mathrm{ha}$ $\mathrm{N}: \mathrm{P}_{2} \mathrm{O}_{5}: \mathrm{K}_{2} \mathrm{O}+0.5 \% \quad \mathrm{ZnSO}_{4}+$ Sesbania green manuring over $\mathrm{T}_{4}$-direct seeded rice with recommended dose of $\mathrm{NPK}+0.5 \% \mathrm{ZnSO}_{4}$ and $\mathrm{T}_{5}$-direct seeded rice with $10 \%$ extra recommended dose of $\mathrm{NPK} 0.5 \% \mathrm{ZnSO}_{4}$, respectively. 


\section{Thousand grain weight (g)}

Maximum thousand grain weight was recorded with $\mathrm{T}_{2}$ - conventional method of transplanting with 180:60:40 $\mathrm{kg} / \mathrm{ha}$ $\mathrm{N}: \mathrm{P}_{2} \mathrm{O}_{5}: \mathrm{K}_{2} \mathrm{O}+0.5 \% \quad \mathrm{ZnSO}_{4}+$ Sesbania green manuring, which is statistically at par with $\mathrm{T}_{1^{-}}$ conventional transplanting with $\mathrm{RDF}$ (150:60:40 $\quad \mathrm{kg} / \mathrm{ha} \quad \mathrm{N}: \mathrm{P}_{2} \mathrm{O}_{5}: \mathrm{K}_{2} \mathrm{O}+0.5 \%$ $\left.\mathrm{ZnSO}_{4}\right), \mathrm{T}_{3}$-conventional transplanting with $10 \%$ extra RDF (165:66:44 kg/ha $\left.\mathrm{N}: \mathrm{P}_{2} \mathrm{O}_{5}: \mathrm{K}_{2} \mathrm{O}+0.5 \% \quad \mathrm{ZnSO}_{4}\right)$ and $\mathrm{T}_{4}$-direct seeded rice with recommended dose of NPK+ $0.5 \% \quad \mathrm{ZnSO}_{4}$,respectively. Significantly minimum thousand grain weight was recorded with $\mathrm{T}_{5}$-direct seeded rice with $10 \%$ extra recommended dose of NPK $0.5 \% \mathrm{ZnSO}_{4}$. It might be due to the availability of higher nitrogen for chlorophyll formation and $\mathrm{Zn}$ influences $\mathrm{N}$ uptake, protein quality and photosynthesis (Pandey et al., 2002).

\section{Biological yield (q/ha)}

Biological yield was significantly higher due to $\mathrm{T}_{2^{-}}$conventional method of transplanting with 180:60:40 $\mathrm{kg} / \mathrm{ha} \quad \mathrm{N}: \mathrm{P}_{2} \mathrm{O}_{5}: \mathrm{K}_{2} \mathrm{O}+0.5 \%$ $\mathrm{ZnSO}_{4}+$ Sesbania green manuring over $\mathrm{T}_{1^{-}}$ conventional transplanting with $\mathrm{RDF}$ (150:60:40 kg/ha N: $\mathrm{P}_{2} \mathrm{O}_{5}: \mathrm{K}_{2} \mathrm{O}+0.5 \% \mathrm{ZnSO}_{4}$ ), $\mathrm{T}_{4}$-direct seeded rice with recommended dose of NPK+ $0.5 \% \quad \mathrm{ZnSO}_{4}$ and $\mathrm{T}_{5}$-direct seeded rice with $10 \%$ extra recommended dose of NPK $\quad 0.5 \% \quad \mathrm{ZnSO}_{4}$, respectively and statistically at par with $\mathrm{T}_{3}$-conventional transplanting with 10\% extra RDF (165:66:44 $\mathrm{kg} / \mathrm{ha} \mathrm{N}: \mathrm{P}_{2} \mathrm{O}_{5}: \mathrm{K}_{2} \mathrm{O}+0.5 \% \mathrm{ZnSO}_{4}$ ). Biological yield was increased 7.64 and 6.22 per cent by $\mathrm{T}_{2}$ - conventional method of transplanting with $180: 60: 40 \quad \mathrm{~kg} / \mathrm{ha} \quad \mathrm{N}: \mathrm{P}_{2} \mathrm{O}_{5}: \mathrm{K}_{2} \mathrm{O}+0.5 \%$ $\mathrm{ZnSO}_{4}+$ Sesbania green manuring over $\mathrm{T}_{4}$ direct seeded rice with recommended dose of $\mathrm{NPK}+0.5 \% \mathrm{ZnSO}_{4}$ and $\mathrm{T}_{5}$-direct seeded rice with $10 \%$ extra recommended dose of NPK $0.5 \% \mathrm{ZnSO}_{4}$, respectively. It might be due to the presence of available nutrients from both organic and inorganic sources. Sesbania fixed the atmospheric nitrogen \& supply to crop.
Hence, $\mathrm{N}$ helps to increase the total biomass of the crop.

\section{Grain yield (q/ha)}

Significantly higher grain yield was recorded with $\mathrm{T}_{2}$ - conventional method of transplanting with 180:60:40 kg/ha $\mathrm{N}: \mathrm{P}_{2} \mathrm{O}_{5}: \mathrm{K}_{2} \mathrm{O}+0.5 \%$ $\mathrm{ZnSO}_{4}+$ Sesbania green manuring over $\mathrm{T}_{1^{-}}$ conventional transplanting with $\mathrm{RDF}$ (150:60:40 kg/ha N: $\mathrm{P}_{2} \mathrm{O}_{5}: \mathrm{K}_{2} \mathrm{O}+0.5 \% \mathrm{ZnSO}_{4}$ ), $\mathrm{T}_{4}$-direct seeded rice with recommended dose of NPK+ $0.5 \% \quad \mathrm{ZnSO}_{4}$ and $\mathrm{T}_{5}$-direct seeded rice with $10 \%$ extra recommended dose of NPK $0.5 \% \quad \mathrm{ZnSO}_{4}$, respectively and statistically at par with $\mathrm{T}_{3}$-conventional transplanting with 10\% extra RDF (165:66:44 $\mathrm{kg} / \mathrm{ha} \mathrm{N}: \mathrm{P}_{2} \mathrm{O}_{5}: \mathrm{K}_{2} \mathrm{O}+0.5 \% \mathrm{ZnSO}_{4}$ ). Grain yield was increased 5.83 per cent by $\mathrm{T}_{2-}$ conventional method of transplanting with 180:60:40 kg/ha $\quad \mathrm{N}: \mathrm{P}_{2} \mathrm{O}_{5}: \mathrm{K}_{2} \mathrm{O}+0.5 \%$ $\mathrm{ZnSO}_{4}+$ Sesbania green manuring over $\mathrm{T}_{4^{-}}$ direct seeded rice with recommended dose of $\mathrm{NPK}+0.5 \% \mathrm{ZnSO}_{4}$. The higher grain yield due to adequate and balance application of nutrients increases the availability and uptake of other essential nutrients resulted in positive effect of many yield components, like number of tillers, number of panicles and 1000 grain weight (Kausar et al., 2001 and Rahman et al., 2001).

\section{Straw yield $(\mathrm{q} / \mathrm{ha})$}

Significantly higher straw yield was recorded with $\mathrm{T}_{2}$ - conventional method of transplanting with 180:60:40 kg/ha $\mathrm{N}: \mathrm{P}_{2} \mathrm{O}_{5}: \mathrm{K}_{2} \mathrm{O}+0.5 \%$ $\mathrm{ZnSO}_{4}+$ Sesbania green manuring over $\mathrm{T}_{1^{-}}$ conventional transplanting with RDF (150:60:40 kg/ha N: $\mathrm{P}_{2} \mathrm{O}_{5}: \mathrm{K}_{2} \mathrm{O}+0.5 \% \mathrm{ZnSO}_{4}$ ), $\mathrm{T}_{4}$-direct seeded rice with recommended dose of NPK+ $0.5 \% \quad \mathrm{ZnSO}_{4}$ and $\mathrm{T}_{5}$-direct seeded rice with $10 \%$ extra recommended dose of NPK $0.5 \% \quad \mathrm{ZnSO}_{4}$, respectively and statistically at par with $\mathrm{T}_{3}$-conventional transplanting with 10\% extra RDF (165:66:44 $\mathrm{kg} / \mathrm{ha} \mathrm{N}: \mathrm{P}_{2} \mathrm{O}_{5}: \mathrm{K}_{2} \mathrm{O}+0.5 \% \mathrm{ZnSO}_{4}$ ) (Table 2). 
Table.1 Growth parameters of rice as influenced by different treatments at different stages

\begin{tabular}{|c|c|c|c|c|c|c|c|c|c|c|c|c|}
\hline \multirow[t]{2}{*}{ Treatments } & \multicolumn{4}{|c|}{ Shoot height (cm) } & \multicolumn{4}{|c|}{ Number of shoots /m } & \multicolumn{4}{|c|}{ Dry matter accumulation $\left(\mathrm{g} / \mathrm{m}^{2}\right)$} \\
\hline & 30DAS & 60DAS & 90DAS & Maturity & 30DAS & 60DAS & 90DAS & Maturity & 30DAS & 60DAS & 90DAS & Maturity \\
\hline $\mathbf{T}_{1}$ & 32.04 & 71.08 & 87.08 & 81.10 & 200 & 282 & 223 & 220 & 38.0 & 140.0 & 262.8 & 814.7 \\
\hline $\mathbf{T}_{2}$ & 37.28 & 75.40 & 96.40 & 90.70 & 234 & 317 & 258 & 257 & 40.5 & 152.0 & 310.4 & 1014.9 \\
\hline $\mathbf{T}_{3}$ & 22.96 & 62.96 & 86.32 & 81.10 & 213 & 319 & 256 & 254 & 39.5 & 148.0 & 327.4 & 962.2 \\
\hline $\mathbf{T}_{4}$ & 21.33 & 60.69 & 83.64 & 76.71 & 229 & 295 & 237 & 233 & 63.4 & 135.0 & 273.2 & 846.9 \\
\hline $\mathbf{T}_{5}$ & 29.62 & 71.52 & 90.52 & 86.60 & 236 & 313 & 254 & 251 & 67.3 & 146.0 & 298.0 & 923.8 \\
\hline SEM \pm & 1.14 & 1.47 & 3.11 & 3.20 & 6.53 & 7.88 & 9.70 & 7.77 & 2.06 & 2.66 & 13.32 & 41.32 \\
\hline CD at $5 \%$ & 3.43 & 4.41 & 9.39 & 9.60 & 19.57 & 23.98 & 29.09 & 23.31 & 6.19 & 8.00 & 39.95 & 123.87 \\
\hline
\end{tabular}

$\mathrm{T}_{1}$-Conventional transplanting with RDF $\left(150: 60: 40 \mathrm{~kg} / \mathrm{ha} \mathrm{N}: \mathrm{P}_{2} \mathrm{O}_{5}: \mathrm{K}_{2} \mathrm{O}+0.5 \% \mathrm{ZnSO}_{4}\right)$

$\mathrm{T}_{2}$-Conventional transplanting with 180:60:40 kg/ha N: $\mathrm{P}_{2} \mathrm{O}_{5}: \mathrm{K}_{2} \mathrm{O}+0.5 \% \mathrm{ZnSO}_{4},+$ Sesbania as green manuring

$\mathrm{T}_{3}$-Conventional transplanting with $10 \%$ extra RDF (165:66:44 kg/ha N: $\left.\mathrm{P}_{2} \mathrm{O}_{5}: \mathrm{K}_{2} \mathrm{O}+0.5 \% \mathrm{ZnSO}_{4}\right)$

$\mathrm{T}_{4}$-Direct seeded rice with recommended dose of NPK and $0.5 \% \mathrm{ZnSO}_{4}$

$\mathrm{T}_{5}$-Direct seeded rice with $10 \%$ extra recommended dose of NPK and $0.5 \% \mathrm{ZnSO}_{4}$

Table.2 Yield attributes and yield of rice as influenced by different treatments

\begin{tabular}{|c|c|c|c|c|c|c|c|c|}
\hline Treatments & $\begin{array}{l}\text { Number of } \\
\text { panicles } / \mathrm{m}^{2}\end{array}$ & $\begin{array}{c}\text { Panicle } \\
\text { length }(\mathrm{cm})\end{array}$ & $\begin{array}{c}\text { Number of } \\
\text { grains / } \\
\text { panicle }\end{array}$ & $\begin{array}{c}\text { Grain weight / } \\
\text { panicle (g) }\end{array}$ & $\begin{array}{c}\text { Thousand } \\
\text { grain } \\
\text { weight (g) }\end{array}$ & $\begin{array}{c}\text { Biological } \\
\text { yield } \\
\text { (q/ha) }\end{array}$ & $\begin{array}{l}\text { Grain } \\
\text { yield } \\
\text { (q/ha) }\end{array}$ & $\begin{array}{c}\text { Straw } \\
\text { yield } \\
\text { (q/ha) }\end{array}$ \\
\hline $\mathbf{T}_{1}$ & 218 & 26.08 & 85.4 & 2.92 & 29.55 & 121.47 & 58.75 & 62.72 \\
\hline $\mathbf{T}_{2}$ & 255 & 26.98 & 92.6 & 3.46 & 30.94 & 129.54 & 62.39 & 67.15 \\
\hline $\mathbf{T}_{3}$ & 252 & 26.11 & 97.3 & 3.30 & 30.18 & 127.06 & 61.27 & 65.79 \\
\hline $\mathbf{T}_{4}$ & 231 & 25.74 & 81.9 & 2.79 & 28.94 & 119.64 & 57.92 & 61.71 \\
\hline $\mathbf{T}_{5}$ & 245 & 24.75 & 88.1 & 2.92 & 26.50 & 121.47 & 58.75 & 62.72 \\
\hline SEM \pm & 9.21 & 0.71 & 4.28 & 0.12 & 1.16 & 1.83 & 0.82 & 1.08 \\
\hline CD at $5 \%$ & 27.61 & 2.14 & 12.85 & 0.37 & 3.49 & 5.59 & 2.47 & 3.02 \\
\hline
\end{tabular}

$\mathrm{T}_{1}$-Conventional transplanting with RDF (150:60:40 kg/ha N:P $\left.\mathrm{P}_{2} \mathrm{O}_{5}: \mathrm{K}_{2} \mathrm{O}+0.5 \% \mathrm{ZnSO}_{4}\right)$

$\mathrm{T}_{2}$-Conventional transplanting with 180:60:40 kg/ha N: $\mathrm{P}_{2} \mathrm{O}_{5}: \mathrm{K}_{2} \mathrm{O}+0.5 \% \mathrm{ZnSO}_{4}$, + Sesbania as green manuring

$\mathrm{T}_{3}$-Conventional transplanting with $10 \%$ extra RDF (165:66:44 kg/ha N: $\left.\mathrm{P}_{2} \mathrm{O}_{5}: \mathrm{K}_{2} \mathrm{O}+0.5 \% \mathrm{ZnSO}_{4}\right)$

$\mathrm{T}_{4}$-Direct seeded rice with recommended dose of NPK and $0.5 \% \mathrm{ZnSO}_{4}$

$\mathrm{T}_{5}$-Direct seeded rice with $10 \%$ extra recommended dose of NPK and $0.5 \% \mathrm{ZnSO}_{4}$ 
It might be due to the favorable effect of integrated nutrient management on the proliferation of roots and thereby increasing the uptake of plant nutrients from the soil and ultimately the vegetative growth of plants.

On the basis of the present investigation, it is concluded that $180 \mathrm{~kg}$ N/ha coupled with green manuring was reflected superior performance among all other treatments. But repeated tillage and puddling system conventionally over years of this treatment, deteriorating the soil structure and ultimately declining the productivity. So, sustainability still remains the issue with this treatment for the future. Though, direct seeded rice with recommended dose of fertilizer and $10 \%$ extra dose of fertilizer was inferior in many aspects but it certainly promises to better productivity of rice crop when the conditions are projected in the future. Moreover, it will helps for increase farm-level productivity, build soil rather than banish soil, conserve natural resources and limit negative environmental impacts which is essential for the sustainability of the system.

\section{References}

Agricultural Statistics, 2018.Agricultural Statistics at a glance. Directorate of Economics and Statistics. Dept. of Agric. and Co-operation. Ministry of Agriculture, Government of India.p.502.

Ahmed, S., Naz, S.Y. and Raja, M.R. 1998.Effect of farm yard manure, crop residues and mineral fertilizers on wheat yield under rainfed conditions. Pakistan Journal of Soil Science. 14(12):111-113

Brar, B. S., Singh, K. and Dheri, G.S. 2013. Carbon sequestration and soil carbon pools in a rice-wheat cropping system: Effect of long-term use of inorganic fertilizers and organic manure. Soil and
Tillage Research. 128: 30-36.

Donald, C.M. and Hamblin, J. 1976. The biological yield and harvest index of cereals as agronomic and plant breeding criteria. In Advances in agronomy, Academic Press., USA 28: 361-405

Ghosh, S.K., Lee, J., Godwin, A.C., Oke, A., Al-Rawi, R. and El-Hoz, M. 2016. Waste management in USA through case studies: e-waste recycling and waste energy plant. In Proceedings of the $31 \mathrm{st}$ international conference on solid waste technology and management, 3-6 April 2016, Philadelphia, USA. Pennsylvania: Widener University.

Hanway, J.J. and Heidel, H., 1952. Soil analysis methods as used in Iowa state. College Soil Testing Laboratory. Iowa Agriculture, 57: 1-31.

Husain, M.M., Haque, M.A., Khan, M.A.I., Rashid, M.M. and Islam, M.F. 2003. Direct wet-seeded method of establishment of rice under irrigated condition. Agriculturist. 1(1): 106-113.

Kausar, M.A., Ali, S. and Iqbal, M.M. 2001. Zinc nutrition of three rice varieties in alkaline calcareous soils. Pakistan Journal of Soil Science. 20: 9-14

Kumar, S., Kumar, R., Mishra, J.S., Dwivedi, S.K., Prakash, V., Bhakta, N., Singh, A.K., Singh, S.K., Singh, S.S., Haris, A.A. and Rao, K.K. 2017. Evaluation of rice (Oryza sativa) cultivars under different crop establishment methods to enhance productivity, profitability and energetics of rice in middle IndoGangetic Plains of India. Indian Journal of Agronomy. 62(3):307-314.

Olsen, S.R., Cole, C.V., Watanabe, F.S. and Dean, L.A. 1954. Estimation of available phosphorus in soils by extraction with sodium bicarbonate. USDA. Circular. USDA, Washington D. C. 939: 1-19.

Pacharne, D.P. 2017. Production potential and 
energy dynamics of efficient cropping systems under diverse nutrient management practices. Indian Journal of Agronomy. 62(3): 280-286.

Pandey, N., Pathak, G.C., Singh, A.K. and Sharma, C.P. 2002. Enzymic changes in response to zinc nutrition. Journal of Plant Physiology. 159(10):1151-1153.

Rahman, A., Yassen, M., Akram M. and Awan, Z.I. 2001. Response of rice to $\mathrm{Zn}$ application and different sources in calcareous soils. Pakistan Journal of Biological Sciences. 285- 287.

Snedecor, G.W. and Cochran, W.G. 1967.Statistical Methods. Oxford and IBH, New Delhi. pp. 381-418

Subbiah, B.V. and Asija, H.L. 1956. A rapid procedure for estimation of the available nitrogen in soils.Current Science. 25: 259-260.
Tomar, R., Singh, N.B., Singh, V. and Kumar, D. 2018.Effect of planting methods and integrated nutrient management on growth parameters, yield and economics of rice. Journal of Pharmacognosy and Phytochemistry. 7(2): 520-527.

Umar, M., Qasim, M. and Jamil, M. 2004.Effect of different levels of $\mathrm{Zn}$ on the yield and yield components of rice in different soils of D.I. Khan, Pakistan. Sarhad Journal of Agriculture. 1(1): 6369.

Walkley, A. and Black, I.A., 1934. An examination of the Degtjareff method for determining soil organic matter, and a proposed modification of the chromic acid titration method. Soil science, 37(1): 29-38.

\section{How to cite this article:}

Arun, E. K. and Brajkishor Prajapati. 2020. Effect of Fertilization Modules on the Growth and Yield of Rice (Oryza sativa L.) in Tarai Region of Uttarakhand, India. Int.J.Curr.Microbiol.App.Sci. 9(05): 3192-3200. doi: https://doi.org/10.20546/ijcmas.2020.905.379 